\title{
NUCLEAR ENERGY PROJECTS FINANCING OPTION WITH CONTRACTS FOR DIFFERENCE: THE PERSPECTIVE FROM EUROPEAN UNION STATE AID MODERNISATION
}

\author{
Laura RIMŠAITÉ \\ Mykolas Romeris University, Faculty of Law \\ Business Law Department \\ Ateities str. 20, LT-08303 Vilnius, Lithuania \\ E-mail: rimsaitel@gmail.com \\ doi:10.13165/IE-13-7-4-04
}

\begin{abstract}
This article deals with the question related to intercourse between the promotions of foreign investments in energy sector, and therefore, with several obstacles according to European Union State aid rules. There is a close relationship between the cost structure of nuclear power, the long-term safety and financial risks associated with some elements of the nuclear fuel cycle, and the high market risk that investors have placed on the technology since its inception. The construction phase of Nuclear Power Plant is considered the most risky for investors, especially for a new nuclear program. Large amounts of capital must be invested early on, while returns will not begin to flow until the plant enters operation some years later. The recent development of State Aid modernisation process at the EU provides more flexibility to implement various financing models, which are crucial for energy infrastructure projects. This paper analyses the recent development in the United Kingdom electricity legislation currently an option to adopt Contracts for Difference model to Hinkley Point C Nuclear Power Plant project and its relation with State aid rules in the light of modernisation process.
\end{abstract}

JEL classification: K21, K23, L51, O13, Q4.

Keywords: competition law, nuclear power plant, contracts for difference, state aid modernisation, investments, power purchase agreements.

Reikšminiai žodžiai: konkurencijos teisè, branduolinè jègainė, susitarimai dèl kainų skrtumo, valstybės pagalba, investicijos, energijos pirkimo sutartys.

\section{Introduction}

Construction risk can be shared with Nuclear Power Plant (hereinafter - NPP) vendors and other contractors actually building the plant through fixed price contracts or through performance related contract clauses. However, in practice, vendors have only a limited capacity for such risk taking. Large, financially strong vertically integrated utilities provide the best environment to finance new NPPs. However, Third Energy package 
no longer supports vertically integrated utilities. An integral part of every energy policy is the need to ensure a secure supply of electricity. On one hand, Member States are encouraged to safeguard security of energy supply; on the other, the scope of actions of the Member States is restricted by the European Union (hereinafter - EU) State aid rules aimed at safeguarding competition on the internal market by preventing excessive interference by the Member States in the electricity market. Although nuclear power is a mature technology that should not need subsidies, it lacks the flexibility to work effectively alongside renewable energy; nuclear power would be eligible for the same system of subsidies as is proposed for renewable sources of power in order to achieve low carbon energy future goals. However, long-term power purchase agreements, which are necessary for investors to ensure safe investment returns, may breach EU competition rules. There is a close relationship between the cost structure of nuclear power, the long-term nuclear safety and financial risks associated with some elements of the nuclear fuel cycle, and the high market risk that investors have placed on the technology since its inception.

The need for the promotion of foreign investments with targets to secure low carbon electricity generation is declared by the European Commission (hereinafter - the Commission). Therefore, support schemes for renewable energy were adopted; however, nuclear energy with its low carbon technology is questionably opted-out from any support mechanisms, which are approved to immature technology as renewable. Despite the lack of global consensus, nuclear energy remains at the energy mix as a technology capable to provide basic electricity generation at competitive price. Therefore, this article analyses the concept of State aid control as nuclear energy projects financing or subsidisation mechanisms have to be notified to the Commission as a consequence timely implementation might be at risk referring to long administrative procedures. In the second part, Contracts for Difference are analysed in detail, as they are adjusted to current nuclear projects to ongoing Hinkley Point C NPP project in the United Kingdom (hereinafter - the UK). Such financing model provides robustness to the existing legislation in the UK, and thus, deprives equal conditions to promotion of low carbon technology. Finally, the Modernisation of State aid process is analysed, as it is closely related to the creation of investment attractive climate and the application of investment promotion schemes to energy projects, not explicitly just renewable technology.

There is a lack of academic scholars that have analysed issues on State aid process and the current financing of NPP projects. Kristiansen analysed several aspects of Contracts for Difference applied in the Nord Pool Spot market model [14]. Jones and Allibert analysed specific State Aid options applied to energy sector [1]. Hancher and Salerno provided insights to the application of State Aid to energy sector [4]. However, there is still a lack of comprehensive insights combining the current state aid measures analysis in the light of the State aid modernisation process at the EU.

The purpose of the research is to analyze the Contracts for Difference in the light of the European Union State aid modernisation process.

The object of the research is Contracts for Difference implementation problems for nuclear power plant projects related to State aid rules.

Research methods include the systematic analysis method used in an integrated way through the competition law analysis of the Court of Justice of the European Union 
(hereinafter - CJEU) practice, the Commission decisions and practical aspects of the application analysis to look at the energy sector and State aid control and identify the most common problems [28]. The application of this method is important in order to find an alternative as well as solve problems and understand the unknown options by examining them. The comparative historical method helps to collate the relevant phenomena in different historical stages of development and fully discloses the origins of the problem and identifies the cause [28].

\section{The origin and concept of State aid control under European Union framework}

State aid rules were an integral part of the Treaty of Rome. The concept of supranational control was an indispensable tool for further European Union integration and creation of internal market, where goods, capital, services and persons circulate freely. A comprehensive competition policy requires an appropriate control of private entities behaviour as well as rules of the potentially anticompetitive State intervention [20]. Articles 107 to 109 of the Treaty on the Functioning of European Union (hereinafter TFEU) regulate granting of the State aid to Member States. An unfair situation when aid is granted to certain undertakings to maintain fragmentation or to obstruct growth is an indispensable measure that complements internal market [23]. In order to be constituted as State aid, the measure must meet the following conditions: the aid has been granted or imposed by a public authority and the measure results in transfer of resources from the State or the State receiving less resources and the aid distorts competition by favouring certain undertakings or the production of certain goods and the products or services in question are traded within the Community. Article 107 prohibits aid granted by a State or through State resources in any form whatsoever, without a distinction as to whether the advantage is granted directly or indirectly [5]. The concept of advantage covers economic advantage which the recipient would not get according to market conditions.

State aid control relates to prevention of anti-competitive behaviour between Member States, as they are taking measures to support the so-called "national champions" or to use certain subsidies in order to attract necessary investments to a territory, thus, distorting competition [21]. The TFEU allows certain exceptions from the previous prohibition to grant aid and measures on certain conditions that might be declared as compatible with the TFEU. The main objective of the State aid control is to distinguish the balancing effects of the measure to competition and internal market and to ensure the common interest.

The evolution of the State aid is closely linked to the European integration process. Retrospectively, State aid rules were developed during five periods since 1960s. There is no precedent or comparable system globally to the one developed by the EU. The World Trade Organisation (hereinafter - WTO) Agreement on Subsidies and Countervailing Measures covers similar objectives; however, it only provides the dispute settlement procedure, but does not cover any legislation related to State aid measures [24]. WTO control on subsidies reflects the trade distortion rather than competition and likewise uses different measures. 
Not all subsidies may have negative effect on the market. A quite recent example of this could be fostering investments to renewable energy to enhance the low carbon energy future goals as well as to ensure further development of immature technology. In 2005, the Commission published the State Aid Action Plan, which is derived for a better targeted approach towards intervention measures and helps to identify whether it is necessary for the development of the market or, on contrary, such measure only distorts competition and favours certain undertakings [25]. State intervention could improve market functioning when it is unlikely to produce efficient outcomes of resources [26]. These issues refer to imperfect information and coordination failures in the market. Also, to have the potential on the increase of economic efficiency, State aid has to lead to an incentive effect. The impact on competition and trade is linked to positive effect of the aid and the impact can be considered at two levels. Firstly, the changes of the recipient's behaviour affect competitors and trigger the adjustments to their behaviour. Secondly, the State intervention to competitive process may have long term incentive effects.

In conclusion, the assessment of negative consequences on competition involves considerations to what extent the competitors are affected. Distortions might be considered from the perspective of consumers benefits.

Referring to the promotion of investments in the energy sector and also the choice to find solutions for the financing of energy infrastructure projects through several measures, such as long term power purchase agreements, Contracts for Difference (hereinafter - CFD), feed-in tariffs, guarantees for bank loans, export credit insurance, exemptions from taxes, are taken into account. Therefore, in order to apply such measures, they have to be in compliance with State aid rules and notified to the Commission. This article mainly deals with the CFD as a choice for financing nuclear energy projects.

Worth mentioning are several cases in nuclear sector, which dealt with power purchase agreements (hereinafter - PPAs). Here, it is important to identify if the power generators get an economic advantage, which they would not get from the market. The Commission declares that all PPAs have a principle of mandatory purchase concerned at the price reviewed periodically in accordance with the principle that total fixed and variable costs of generating electricity and a profit margin are passed to a consumer [7]. The contracts are settled up to twenty years from the beginning of operation of the plant, whereas commercial risk associated with operation of power plants is endured by the buyer of electricity. It includes risk related to fluctuations in electricity generation costs (fuel costs) and also risk associated with fluctuation in end-user electricity prices and electricity demand. The longer the period, the greater the value of guarantee, as it protects against a risk, which occurrence is unpredictable. In the Polish case, the Commission considered that the arrangement amounted to a guarantee, which preconditions were a better economic situation for beneficiaries than other companies in the market [7]. The PPAs in this case just provided a payment by the State-owned and Statecontrolled company PSE of the investment costs and operating costs of the power plants, which were parties to the agreements.

What regards long term PPAs, they are limited to 15 years, considering that such period does not preclude an abuse of dominant position and market foreclosure, as nuclear power investment payback period is about 30 years. The Commission considers that such 
period is sufficient for the investment return and to continue process on competitive conditions in the market along with other operators [10]. Cases referring to long term PPA's are discussed next. In Scottish Nuclear, Nuclear Energy Agreement cases, the Commission held that the PPA was set with take-or-pay obligations, considering that nuclear power plant produced electricity was sold under a long-term 30 year contract, and awarded to the two supply companies. The Commission ingeminated its decisions in consequent cases, noting that long-term contracts of nuclear power electricity supply should not exceed 15 years [11]. In those cases, the Commission found that the electricity supply contracts were awarded solely between electricity producers and the generation undertakings. When entities decide to conclude such agreement in order to cover major primary investments for the projects that require long term investment return period, the market remains closed for that time. Other case covers a situation, where a compromise was reached due to the pricing periods, whereas for the first fifteen years generator set higher prices, and for the remaining period lower electricity sales prices were negotiated [22]. Also, it is important to pay attention to the Commission's decision in ISAB Energy case, where the twenty-year long-term PPA has not been cancelled; however, the Commission saved the reservation after fifteen years to check on market functioning [19].

The Commission's position on the NPP's generated electricity supply contract is compromise in a sense, that such contracts are necessary to ensure long-term security of energy supply and secure the massive investment return of nuclear energy infrastructure installation.

\section{Electricity market reform in the UK: Fostering investments with Contracts for Difference}

The Commission stresses out that the need for the creation of common internal energy market remains at the outset of crucial importance. However, not all Member States transposed necessary legislation ${ }^{1}$ to their national laws, and only well-functioning internal energy market fosters necessary investments into generation. The Commission seeks market opening, increased cross-border change, market integration and stronger competition in order to ensure a level playing field, whereas companies are treated equally, and to put all necessary efforts to make progress on the development infrastructure, by removing bottlenecks. Also, an important factor is a strong and independent regulator, who helps to enforce internal market rules.

Referring to Kyoto protocol, counties reflect the need to cut emissions of greenhouse gases notably from burning fossil fuel, thus, implementing necessary legislation.

1 The first energy law package includes: Gas Directive 98/30/EC, Electricity Directive 96/92/EC. The second package includes: Gas Directive 2003/55/EC, Electricity Directive 2003/54/EC. The third energy package includes: Electricity Directive 2009/72/EC, Gas Directive 2009/73/EC, as well as three regulations: On conditions for access to the natural gas transmission networks (EC) No 715/2009; On conditions for access to the network for cross-border exchanges in electricity (EC) No 714/2009; Establishing an Agency for the Cooperation of Energy Regulators ACER (EC) No $713 / 2009$. 
According to OECD information, nuclear energy takes an important part as the second largest low carbon source behind hydro energy [27]. However, the share of nuclear energy depends on various factors, such as national energy policy, economic and investment climate, public acceptance, as well as the rate of commercial deployment of carbon capture storage and renewable energy.

The United Kingdom intends to continue new build plans, and the best expression of that is construction plans for Hinkley Point C NPP Station, and preparatory works, including legislative framework adjustments, are ongoing. Quite controversial option of financing was chosen to implement financial derivative instrument, which would be constrained as State aid measure. Therefore, necessary amendments to the UK legislation are done, but, according to the existing EU legislative base, there is still a need to get clearance from the Commission on acceptance of such mechanism.

In the UK, Electricity market reform was initiated in July 2011, with incentive to reach decarbonisation targets and also to foster investments in low carbon electricity generation [11]. The reform introduces capacity market, targets decarbonisation goals and it also provides streamlined approach to the enhancement of investments to low carbon electricity generation, thus, it provides security of supply at competitive price to customers [17]. The generators participate in the auctions, where they have to ensure that they have the sufficient capacity to provide electricity in the appropriate period of time. Such amendments provide the insurance for the future blackouts and also offer a possibility for customers to receive electricity at affordable costs.

The most controversial tool introduced during the Electricity market reform was CFD. These measures were set in order to attract necessary investments to energy infrastructure and to put pressure on electricity price for a medium term and also to make the investments in nuclear energy viable. Losses to the investments will have a serious impact on the economy of the UK. Due to international arrangements, the UK puts efforts to cut emissions, thus, to build a new low carbon generation capacity and to ensure security of energy supply [13]. Such instrument was introduced in order to strike a balance between industries that are at the highest risk and, consequently, to minimise additional costs to customers.

Similar instruments can be found adopted in the renewable energy sector. The idea to support investments into renewable energy sector was that such technology is new and able to provide low carbon electricity generation. The Member States introduced measures that facilitated investments entry into the market, such as provisions related to independent private providers, grid access regulations and streamlined licensing procedures. Also, to reduce revenue risks, regulatory interventions, such as price guarantees (feed-in-tariffs), power purchase agreements, quantity guarantees, are being used, as well as fiscal interventions, to remove constraints on investment incentives. However, such measures are only approved to foster investments into the renewable energy development, and nuclear energy remains beyond. Such provisions are rather doubtful as the Commission possess the view of low carbon energy future and, to that extent, nuclear energy takes an important part, but measures, which are immensely necessary to enhance investments and to stabilise risks in nuclear sector, are not in favour. Therefore, the UK's introduced CFD might adhere to possible allegations of State aid rules according to the 
TFEU Article 107(1), as the stabilisation of the above-market price revenue streams to an advantage that will be granted to generators, despite the fact that similar measures to renewable energy are applied widely in the Member States and are approved by national legislators. The question rises why a measure, which reflects Commission's view to enhance investments, and thus, to ensure low carbon energy future goals when is applied to nuclear sector, is treated differently than the same measure applied in renewable energy?

The CFD is a bilateral contract, where an energy producer or a seller receives a fixed price for energy plus an adjustment value to cover the differences between the agreed fixed price and the actual market price of the energy at the time it is delivered. CFD energy prices are usually set low to insure that the energy is bought, but both the buyer and the seller run risks of high or low spot prices at the time the energy is delivered. Such mechanism results that generators neither suffer nor benefit from price volatility. The CFD is a contract that has been used historically in relation to the power market, where one party wants to fix the price they are buying power at, and where the power being delivered is at a variable price; therefore, CFDs were widely used in relation to the old Electricity Pool. According to the latter model, generators deliver power to the Pool and receive Pool Prices, which vary on a half hour by half hour, and they go to a supplier or a trading house and buy a CFD that would provide them with longer term price security. Equally, suppliers would buy from the Pool, and then use a CFD with a generator or a trader to fix the price at which they purchased energy. The generator is being offered a fixed CFD price for their generation. This price is a combination of a power price, which varies with the market, and a subsidy, which is a balancing payment that when added to the power price becomes a fixed amount [12]. This means that the subsidy can be equally negative as well as positive. It is also important to analyse the process of CFD purchasing, as it is possible to sell the power on a half-hourly price to the purchaser of last resort. However, such option might be at a significant discount and unpredictable, and therefore, reduce the level of the CFD price. The alternative would be to enter into an agreement with a supply company, which would take physical delivery of the power and deliver that to their customers.

A generator intends to contract the value of the PPA that minimises a risk under the CFD, otherwise he has to take the risk that the prices diverge over time. The price that is being paid to the generator in its PPA is the market price minus the discount which is related to the size and type of generator and contractual risks associated with the requirements of that generator.

A supplier has intentions to buy physical power and to fix the price that it buys to match the customers that it is selling power to. Currently, half hourly customers and large business contracts are fixed over a period of twelve to twenty four months. The supply company can lock into these contracts if it has bought the power or has bought forward an instrument that fixes the power value. Domestic contracts can be changed more frequently, but this reflects to high level fluctuations in the market, and supplier wants to avoid a more than annual price change. This pressure is added to by the fact that more domestic electricity customers are opting to buy power on a fixed tariff; however, the supply company wants to buy fixed price contracts over the period of time, where the fixed value goes to the generator, and the variable cost goes to the supply company. 
One way to fix the cost would be for the supply company to own the generation that offers a PPA. It would then take over the CFD internally and be able to have a fixed cost of power. However, for those generators that are not owned by one of the utilities, they are offering a non-fixed power price to the supply companies. In this way, the generator wants to maintain their fixed position, so someone needs to take the variable position to allow this work. It would be necessary for the generator or the supply company to be able to fix this power price, when taking physical delivery. This may be done through another CFD type instrument.

For a supplier to buy power from a generator under a CFD arrangement and to get a longer term fixed price to match the requirements of the delivery of power, a supplier or a generator needs to do one of the following steps: he has to be part of a vertically integrated company, both owning and trading in power, or buy another CFD or similar financial derivative in the market that would provide a fixed price, which would be passed onto the generator to ensure the strike price is sufficiently high to cover the discount exposure.

There is still the issue of the timing of a strike ${ }^{2}$ price, which would be minimal comparing to the daily issue created with a daily strike price. Despite delivering reliable and affordable power, the electricity market will not deliver major investments necessary to provide the generation portfolio to meet the decarbonisation targets. The CFD works by stabilising revenues for generators at a fixed price level known as the strike price, where generators receive revenue from selling their electricity into the market as usual. When the market reference price ${ }^{3}$ is below the strike price, they will also receive a top-up payment from suppliers for the additional amount [3]. Conversely, if the reference price is above the strike price, the generator must pay back the difference.

The idea of the strike price to cover the long-run costs of low carbon technology is quite controversial and the question remains if the price has to be set referring to electricity market price or rather referring to investment costs, which has been experienced by the developer. Currently, the strike price is being set according to negotiations between the Government and the promoters of the Hinkley Point C NPP project. Thus, doubt remains when setting the strike price: the inclusion of cost overruns might be included, although such concern is denied if the inflation of costs is introduced into the strike price and nuclear generation technology remains uncompetitive. However, when discussing the balance on setting the strike price, it is necessary to take into account the idea of this mechanism, as it introduces the promotion of investments and secures the occurred investment returns in a timely manner. Of course, this measure is considered as State intervention into the market and might be discussed as opposing the internal market liberalisation idea. In order to evaluate the concept of this mechanism, it is important to take a systematic view at the EU legislation and idea to create internal liberalisation, where not only unbundling of vertically integrated utilities remains at the outset,

2 The strike price will be indexed annually by reference to the change in the Consumer Price Index. Strike prices will be set for five year periods, with the first five year set of strike prices (from 2014 to 2018) to be decided by the Government by late 2013 .

3 Reference price is understood as the market price for electricity that is referenced in the CFD for the purpose of calculating CFD payments. 
but also ensuring sufficient electricity generation to target secure and sustainable energy market. Referring to the creation of internal energy market, the immense necessity to address climate change goals, current decarbonisation targets and foster low carbon energy technologies reflect legally approved interventions into the market, which lead not to distortions, but rather to further enhancements of sustainable market growth. In this regard, eligibility to introduce legally approved mechanisms for nuclear energy would be a continuous reflection of introduced energy policy priorities and would eliminate existing facilitation disproportion between low carbon electricity generation technologies.

Under the revised proposals, a new central CFD counter-party body (hereinafter $\mathrm{CPB}$ ) is to be established. The $\mathrm{CPB}$ will be a private sector non-for profit entity owned by the Government [12]. The CPB will have a revenue raising power to enable it to collect funds from licensed suppliers to meet the payments to generators. It will also calculate and settle payments with suppliers and generators. In addition, costs of the CPB will be recoverable from the industry. The system operator (National Grid in the UK) will administer the decisions on CFD strike prices and the amounts of low-carbon generation, which are contracted, and in a current period it runs the CFD application system, which also determines applicant's eligibility for a CFD according to the set criteria.

The Draft Operational Framework, published with the Energy Bill, includes these elements: price setting mechanism, contractual clauses, security requirements for payment and changes of laws [2]. Payment under the CFD will be dependent on the generator passing various milestones designed to ensure that construction progresses in a timely manner. The Government proposes to cap payments to an amount equal to the value of the contract strike price to try and mitigate this risk.

The payment obligation on the $\mathrm{CPB}$ will be conditional to receive money from suppliers. There is a protection for generators to back up this payment obligation, which reflects to giving generators and their funders a good level of comfort, when the obligation will be placed on suppliers requiring them to pay the amounts demanded from them by the CPB [9]. This will be set out in secondary legislation and will also be reflected in the licences of suppliers. A breach of licence includes the financial penalties (of up to $10 \%$ of annual turnover) and even cancellation of the supplier's licence [9]. Suppliers and generators that are required to make payments will be obliged to post a guarantee to cover future payment periods. Should payment not be made by a supplier and the guarantee is insufficient, the loss would be spread amongst all suppliers. If a supplier becomes insolvent, the payments will be taken over under the supplier of last resort or special administration regime [9].

The Government considers that not all costs and risks associated with generation should be passed through under the CFD contract. The Government has recognised that change in law should be drawn widely enough to include not just change to legislation, but also regulatory instruments. The termination of the CFD covers counterparty right to terminate the contract in prescribed circumstances, including failure to meet the milestone, failure to satisfy a condition precedent, prolonged force majeure, or a generator event of default [12]. In the case of termination for an event of default, the generator will pay a termination payment. The contract will afford generators remedy periods for most events of default. 
Conditions precedent requirement is important on the generator to fulfil certain conditions prior to its entitlement to receive and to make payments [13]. The generator has a duty to keep the CFD counterparty informed to progress towards fulfilling the conditions precedent; the latter will raise funds through the supplier obligation to make payments under the contract, and its liability will not exceed the amount that it receives under the supplier obligation and allocated to the contract [13]. The variability of CFD payments may introduce certain risks, as the volume that is supported by the mechanism might fluctuate during the time period. However, such mechanism provides long term certainty to investors into low carbon energy generation.

The new proposed measures will provide significant comfort to the industry, where it removes concerns and uncertainties between generators and suppliers. It also addresses, to some extent, the non-payment risk, which will be decisive instrument to investors' engagement. The introduction of such measure is at the outset to provide the streamlined approach towards the initiative of low carbon energy goals as well as the promotion of investments, which leads to economy growth and consecutive implementation of the referred goals. In order to adopt the CFD measure to nuclear energy, necessary amendments at EU legislation has to be done, otherwise such mechanism might be approved only under individual notification scheme by the Commission if requirements are met, but it would be limited to ad hoc implementation in spite of being a part of wider legislation that consequently supports promotion of investments to meet low carbon energy targets.

\section{State Aid modernisation: Environmental and Energy guidelines}

Within the objectives to foster growth, focus enforcement cases also to target sustainable growth policy Commission has launched a Communication on State Aid modernisation [8]. So, to ensure targets of creating common internal market, it is important to take two aspects in advance. First, it is necessary to create instruments for integrated market without borders. Second, it is important to establish common market regime, which is not being distorted by anticompetitive behaviour. Therefore, the State aid control mechanism is of crucial importance to achieve these goals. In this Communication, the Commission notices the importance of Europe 2020 strategy for sustainable growth. Modernisation process will serve as a tool that limits competition distortions, thus providing the level playing field in the process of internal market creation, and also targets better implementation of the Europe 2020 Strategy for sustainable growth [6]. Stronger and better targeted State aid requirements would encourage the design of more effective growth-enhancing policies and ensure that competition distortions remain limited.

Energy policy is the area of great significance for the Member States and for the EU. An integral part of every energy policy is the need to ensure a secure electricity supply. It is very important to balance the security of energy supply and sustainable development of energy at EU level. From a safety perspective, the nuclear power industry is highly regulated and can be prone to fluctuating views on how plant construction and operating quality can be assured. Therefore, when regulatory requirements changes are interpreted 
more stringently than expected, the cost of adhering to regulation can increase the total sum of plant completion costs and output economics.

As the Commission stresses out that robust State aid control is an essential instrument to ensure a well-functioning internal market, the initiative in the Environmental guidelines now also provides the rules and procedures for the Energy sector, thus reflecting to a better targeted and streamlined approach to attract necessary investments into electricity sector [14]. Also, such amendments speed the promotion of energy efficiency as well as cross-border interconnections by strengthening internal energy market. This paper reflects support to low carbon electricity generation, thus promoting the marketbased support instruments. However, the modernisation proceedings are not finished, and therefore, it is not clear yet how the final provisions related to support of low carbon technology will be reflected in this paper.

It is also at the utmost important to balance the positive and negative impacts of State aid measure, which is the application of measure, which distorts competition in market. In this regard, the Member States often face difficulties with delays of NPPs because of notification of State aid scheme and approval from the Commission. In regard of State aid modernisation, also into account should be taken the possibility to refuse the obligation for the Member States to notify the Commission on further measures that might be considered as State aid, and therefore, to leave the responsibility for the Member States to ensure that such measure is in line with EU Competition Law. Of course, such proposal does not eliminate Commission's right to control the Member States whether their proposed State aid scheme is in line with the Competition Law. Especially important is to discuss the excising administrative burdens according to EU State Aid rules, which create obstacles for the creation of investor attractive climate. The most striking example of the variety of supranational state aid control rules is the difference between the WTO and the EU systems. WTO rules do not provide for any ex ante control. The control is ex post and allows a Member State to challenge the subsidy granted by another Member State before the WTO dispute settlement body; however, European system provides ex ante and ex post control system.

Due to this modernisation process, which reflects support to investments in energy sector, specifically to promote low carbon technology development, thus to meet the Energy 2020 goals, the amendments introduced in the UK electricity market reform might have a strong argument favouring measures, such as the CFD, that might get a clearance from the Commission as a measure that serves in favour to enhance internal energy market, secures energy supply and helps to create investor attractive climate.

\section{Conclusions}

Competitiveness of nuclear power strongly depends on the cost of financing, due to the high share of fixed capital costs in the total lifetime costs of nuclear power. It is important to stress that EU framework settles preconditions to investment friendly environment to attract possible investors in NPPs projects and also to provide clear and sustained policy support for the development of nuclear power. Such measures ensure that 
market regulation would be incentive for investments reflecting the long-term nature of nuclear power projects.

Contracts for Difference were initially introduced by the UK Government in order to balance the nuclear and renewable incentives on investment. These contracts set a guaranteed price for electricity, which is called the strike price and which ensures paying the difference to the generator if the wholesale price falls below the strike price. Such measure stabilizes costs at a certain level and jointly puts efforts to enhance investment into electricity market. Despite the benefits to the investments under existing regulation, such measure has to be notified to the Commission and receive clearance as referring to the current legislation. Only the renewable energy support schemes are approved at EU level.

The Commission introduced State aid modernisation initiative in order to foster the economic growth and also to focus enforcement activities to the most significant cases as well as to streamline the rules for faster decision making. Such modernisation process introducing amendments to Environmental and Energy Aid guidelines should balance the environmentally friendly investments, thus minimizing the harm and market failures, and may serve as a corner stone for further development of low carbon energy industry, including nuclear. If the Commission approves these amendments, including promotion of investments into energy sector, the CFD might become a strong precedent for the Member States to provide legally approved support schemes to nuclear energy projects development.

\section{References}

1. Allibert, B.; Antoniadis, A.; Battista, J. et al. EU Competition Law. Vol. IV. Book Two. Belgium: Claeys and Casteels, 2008.

2. Annex A. Feed-in Tariff with Contracts for Difference. Operational Framework [interactive]. [accessed on 24-09-2013]. <https://www.gov.uk/government/uploads/ system/uploads/attachment_data/file/66554/7077-electricity-market-reform-annex-a.pdf $>$.

3. Annex B. Feed in Tariff: Contracts for Difference Draft Operational Framework [interactive]. [accessed on 24-09-2013]. <https://www.gov.uk/government/uploads/ system/uploads/attachment_data/file/48373/5358-annex-b-feedin-tariff-with-contracts-for-differe.pdf $>$.

4. Cabau, E. ; Hancer, L.; Jones, Ch. EU Energy Law Volume II EU Competition Law and Energy Markets. Belgium: Claeys and Casteels, 2011.

5. Case T-445/05 Associazione italiana del risparmio gestito and Fineco Asset Management $v$ Commission [2009] ECR II-289.

6. Commission Communication "Europe 2020 - A Strategy for Smart, Sustainable and Inclusive Growth". COM (2010) 2020 final.

7. Commission Decision, OJ 2007 L and OJ 2009 L225/53 (Hungary), Poland: Commission Decision of 25.09.2007, OJ [2009] L83/1. Hungary: Commission Decision of 04.06.2008, OJ [2009] L225/53. 
8. Communication from the Commission to the European Parliament, the Council, the European Economic and Social Committee and the Committee of Regions State Aid Modernisation (SAM). COM (2012) 209 final.

9. Draft Contracts Terms [interactive]. [accessed on 24-09-2013]. <https://www.gov. uk/government/uploads/system/uploads/attachment_data/file/227071/CfD_contract_amended.pdf $>$.

10. EEC 91/329; Commission Decision of 30 April 1991 relating to a proceeding under Article 85 of the EEC Treaty (IV/33.473 - Scottish Nuclear, Nuclear Energy Agreement).

11. Electricidade de Portugal/Pego Project (Notice pursuant to Article 19(3) of Regulation 17) [1993] OJ C265/3.

12. Electricity Market Reform: Policy Overview. November 2012 [interactive]. [accessed on 20-09-2013]. <https://www.gov.uk/government/uploads/system/uploads/attachment_data/file/65634/7090-electricity-market-reform-policy-overview-.pdf>.

13. Electricity Market Reform - Ensuring Electricity Security of Supply and Promoting Investment in Low-carbon Generation [interactive]. [accessed on 23-09-2013]. $<$ https://www.gov.uk/government/uploads/system/uploads/attachment_data/ file/197904/cfd_ia_may_update.pdf>.

14. Electricity Market Reform. Eligibility for an Exemption from the Costs of Contracts for Difference [interactive]. [accessed on 24-09-2013]. <https://www.gov.uk/government/uploads/system/uploads/attachment_data/file/210724/bis-13-974-electricity-market-reform-consultation-eligibility-for-an-exemption-from-the-costsof-contracts-for-difference.pdf $>$.

15. Environmental and Energy Aid Guidelines 2014-2020 Consultation paper. 11 March, 2013 [interactive]. [accessed on 24-09-2013]. <http://ec.europa.eu/competition/state_ aid/legislation/environmental_aid_issues_paper_en.pdf>.

16. European Commission, Communication from the Commission to the European Parliament, the Council of the European Economic and Social Committee and the Committee of the Regions: EU State Modernisation (SAM) of 8 May 2012. COM (2012) 209 final.

17. Explanatory notes referred to Energy Bill [interactive]. [accessed on 23-09-2013]. <https://www.gov.uk/government/uploads/system/uploads/attachment_data/ file/65645/7118-energy-bill explanatory-notes.pdf $>$.

18. Kristiansen, T. Pricing of the Contracts for Difference in the Nordic Market. Energy Policy. 2004, 32(9): 1075-1085.

19. ISAB Energy (Notice pursuant to Article 19(3) of Regulation 17) [1996] OJ C138/3.

20. Martin, S.; Strasse, Ch. La politique communautaire des aides d'Etat est-elle une politique de concurrence? Concurrences. 2005, 3.

21. Medreder, W.; Pesaresi, N.; Hoof, M. EU Competition Law. Belgium: Claeys and Casteels, 2008.

22. REN/Turbogas (Notice pursuant to Article 19(3) of Regulation 17) [1996] OJ C118/7.

23. Rydelski, M. The EC State Aid Regime - Distortive Effects of State Aid on Competition and Trade. London: Cameron May, 2006. 
24. Slocock, B. EC and WTO Subsidy Control Systems - Some Reflections. The European State Aid Quarterly. 2007, 2: 249-256.

25. State Aid Action Plan. Less and Better Targeted State Aid: A Roadmap for State Aid Reform 2005 to 2009.

26. Stiglitz, J. E. Economics of the Public Sector. 3rd revised edition. New York: W. W. Norton \& Co, 2000.

27. Nuclear Energy Agency. OECD. The Role of Nuclear Energy in the Low Carbon Future. 2012 [interactive]. [accessed on 10-10-2013]. <http://www.oecd-nea.org/ nsd/reports/2012/nea6887-role-nuclear-low-carbon.pdf $>$.

28. Tidikis, R. Socialiniu mokslu tyrimu metodologija [Social Sciences Research Methodology]. Lietuvos teisès universitetas, 2003.

\section{BRANDUOLINĖS ENERGETIKOS PROJEKTŲ FINANSAVIMAS TAIKANT SUSITARIMUS DĖL KAINŲ SKIRTUMO: EUROPOS SĄUUNGOS VALSTYBĖS PAGALBOS MODERNIZAVIMO PERSPEKTYVA}

Santrauka. Straipsnyje nagrinėjamas valstybès pagalbos ir investicijų skatinimo priemonių santykis atsižvelgiant ị Europos Sąjungoje vykstantị valstybès pagalbos modernizavimo procesą bei vystomus branduolinès energetikos projektus. Atsižvelgiant ị esamą tiesioginę sąsają tarp branduolinès jègainès vystytojo patiriamų kaštų ir poreikio užtikrinti tinkamus saugos standartus bei proporcingą investicijų grąžą, Jungtinejje Karalysteje ịgyvendinamam branduolinès jejgainès projekto Hinkely Point $C$ finansavimui užtikrinti buvo pasiūlyta taikyti susitarimus dèl kainų skirtumo, kurie iki šiol jau yra taikytini atsinaujinančių energijos išteklių skatinimui ir tokios schemos yra patvirtintos pagal Europos Sąjungos teisès nuostatas. Branduolinès jègainès laikomos mažai anglies dioksido išskiriančiomis technologijomis, kurių plettra prisideda prie klimato kaitos strategijos tikslų igyvendinimo. Paradoksalu, tačiau siekiant šių tikslų yra pripažistamas tik atsinaujinančios energetikos technologijų vystymas, o branduolinės energetikos projektų finansavimas iki šiol išlieka keblus dèl griežtų valstybės pagalbos reikalavimų. I̦vertinus ES vykstantị valstybės pagalbos modernizavimo procesą, išlieka tikimybè, kad paramos schemos gali būti ịtvirtintos ir branduolinès energijos projektų finansavimui užtikrinti.

Laura RIMŠAITE், Mykolas Romeris University, Faculty of Law, Department of Business Law, lecturer, doctoral student. Research interests: Energy law, Competition law, European Union law.

Laura RIMŠAITE் - Mykolo Romerio universiteto Teisès fakulteto Verslo teisès katedros lektoré, doktorantė. Mokslinių interesų kryptys: energetikos teisè, konkurencijos teisé, Europos Sajungos teisè. 